\title{
IMPLEMENTASI MODEL THINK PAIR SHARE (TPS) DALAM MENINGKATKAN PEMAHAMAN PERANAN POLITIK LUAR NEGERI INDONESIA PEMBELAJARAN PKN DI KELAS VI.B SD NEGERI 26 LUBUKLINGGAU
}

\author{
Taryana \\ Guru SD Negeri 26 Lubuklinggau \\ Surel:taryana@gmail.com
}

\begin{abstract}
In Civics subjects, the development of affection and character values must be a priority. What does it mean to be smart academically without being balanced with noble character and morals. In the context of developing affection and character values, the role of the teacher is very important. This is because the teacher is a figure that many students emulate, especially at the elementary level. The teacher is not enough to set an example, but must be an example. The objectives to be achieved in this study are to improve understanding of the role of Indonesian foreign policy in Civics learning in class VI.B SD Negeri 26 Lubuklinggau by using the Think Pair Share (TPS) type cooperative model. This research was conducted at Jalan Kenanga II Kel. Kenanga Kec. Lubuklinggau Utara II, the city of Lubuklinggau SD Negeri 26 Lubuklinggau. Research time in the even semester of January-March 2016/2017 school year. The class that is the research subject is class VI.B SD Negeri 26 Lubuklinggau, which has 25 students on the subject of understanding the role of Indonesian foreign policy in the era of globalization. Based on the results of the research that has been stated in the previous chapter, the conclusion that can be drawn in this study is that the Think Pair Share (TPS) type cooperative learning model has a positive impact in improving the Civics learning outcomes of class VI.B SD Negeri 26 Lubuklinggau students which are marked with an increase in students' learning completeness in each cycle, namely pre-cycle, cycle I and cycle II, respectively $60.00 \%, 72.00 \%$ and $88.00 \%$. The application of the Think Pair Share (TPS) type cooperative learning model has a positive effect, namely it can improve student learning outcomes as indicated by the average student's answer which states that students are interested and interested in the Think Pair Share (TPS) type of cooperative learning model. )) so that they become motivated to learn.
\end{abstract}

Keywords: Civics, Think Pair Share, The Role of Indonesian Foreign Policy

\begin{abstract}
Abstrak
Dalam mata pelajaran PKn, pengembangan nilai-nilai afeksi dan karakter harus menjadi prioritas. Apalah artinya pandai secara akademik tanpa diimbangi karakter dan akhlak mulia. Dalam rangka pengembangan nilai-nilai afeksi dan karakter ini, peran guru amat penting. Sebab, guru adalah figur yang banyak dicontoh muridnya, terutama untuk tingkat SD. Guru tidak cukup memberi contoh, namun harus dapat menjadi contoh. Tujuan yang akan dicapai dalam penelitian ini adalah untuk meningkatkan pemahaman peranan politik luar negeri indonesia pembelajaran PKn di kelas VI.B SD Negeri 26 Lubuklinggau dengan
\end{abstract}


menggunakan model kooperatif tipe Think Pair Share (TPS). Penelitian ini dilaksanakan di Jalan Kenanga II Kel. Kenanga Kec. Lubuklinggau Utara II kota Lubuklinggau SD Negeri 26 Lubuklinggau. Waktu penelitan pada semester genap bulan Januari-Maret tahun pelajaran 2016/2017. Kelas yang menjadi subjek penelitian adalah kelas VI.B SD Negeri 26 Lubuklinggau yang peserta didiknya berjumlah 25 orang siswa pada pokok bahasan memahami peranan politik luar negeri Indonesia dalam era globalisasi. Berdasarkan hasil penelitian yang telah dikemukakan pada bab sebelumnya, maka kesimpulan yang dapat diambil dalam penelitian ini adalah Model pembelajaran kooperatif tipe Think Pair Share (TPS)) memiliki dampak positif dalam meningkatkan hasil belajar PKn peserta didik kelas VI.B SD Negeri 26 Lubuklinggau yang ditandai dengan peningkatan ketuntasan belajar peserta didik dalam setiap siklus, yaitu pra siklus, siklus I dan siklus II masing-masing 60,00\%, 72,00\% dan 88,00\%. Penerapan model pembelajaran kooperatif tipe Think Pair Share (TPS)) mempunyai pengaruh positif, yaitu dapat meningkatkan hasil belajar peserta didik yang ditunjukan dengan rata-rata jawaban peserta didik yang menyatakan bahwa peserta didik tertarik dan berminat terhadap model pembelajaran kooperatif tipe Think Pair Share (TPS)) sehingga mereka menjadi termotivasi untuk belajar.

Kata Kunci: PKn, Think Pair Share, Peranan Politik Luar Negeri Indonesia

\section{PENDAHULUAN}

Mencermati hakikat Pendidikan Kewarganegaraan (PKn), seharusnya ia menjadi pelajaran penting. Bukannya dipandang mata pelajaran sampingan. PKn tidak kalah penting dibanding mata pelajaran lainnya. Tapi mengapa selama ini PKn cenderung kurang diminati siswa? Mengapa PKn kurang mendapat perhatian seperti pelajaran matematika, IPA dan bahasa Indonesia? Apakah karena PKn tidak di-UN-kan di tingkat sekolah dasar (SD)?.

Pertama, kurikulum yang terlalu berat. Menurut penulis, konten kurikulum PKn untuk tingkat SD terlalu tinggi dibandingkan kemampuan anak usia SD. Misalnya, Karena kesalahan menangkap esensi SK dan KD, pembelajaran cenderung cuma mengarah pada pencapaian aspek kognitif. Kondisi itu menyebabkan kompetensi yang diharapkan dicapai siswa malah terabaikan. Misalnya bagaimana siswa mampu menghargai semangat para pejuang dalam merumuskan Pancasila, bagaimana menghargai perbedaan pendapat dalam suatu musyawarah, dan bagaimana meneladani nilai juang para tokoh yang oleh siswa dapat diaplikasikan dalam belajar. Dan ternyata ini juga terjadi pada tim penyusun soal ujian 
tingkat kabupaten. Padahal kata kunci dari SK dan KD itu "menghargai dan nilai-nilai juang",sehingga semestinya pembelajaran menekankan pada aspek afektif dan perilaku siswa.

Mengajar berdasarkan buku teks (textbook centre). Buku teks selama ini menjadi pegangan wajib. Jika kita mengajar cuma mengandalkan buku teks (tanpa menggunakan RPP), arah dan sasaran pembelajaran menjadi tidak fokus. Praktek mengajar PKn selama ini lebih banyak berlangsung dengan pendekatan konvensional. Selama mengajar, guru lebih banyak menggunakan metode ceramah dan tanya jawab. Siswa cuma menjadi pendengar di dalam kelas, kemudian menjawab soal. Pembelajaran berlangsung monoton, dan guru menjadi satu-satunya sumber informasi. Selain itu, mengajar PKn jarang menggunakan media yang menunjang. Pembelajaran seperti ini jelas amat membosankan.

Pertanyaan itu muncul bila melihat kenyataan bahwa sebagian besar siswa bahkan orangtua sepertinya menganggap remeh pelajaran ini. Sesuatu yang dianggap remeh akan berdampak remeh pula pada hasilnya. Alhasil, pencapaian tujuan PKn pun kurang maksimal.

Apakah kita lalu menyalahkan siswa? Tentu tidak. Sudah saatnya kita sebagai pendidik melakukan introspeksi. Apakah selama ini kita sudah mengajar secara baik? Mengapa siswa kurang tertarik belajar PKn? Mengapa belajar PKn katanya membosankan? Dan masih banyak pertanyaan yang dapat memicu kita me-review cara mengajar.

Masalah yang dialami setiap pembelajaran memang amat kompleks. Masalah itu datangnya bisa dari kurikulum, guru, siswa, sarana prasarana, sumber belajar, dan lainnya. Tapi sayangnya banyak pendidik kurang peka terhadap permasalahan yang dihadapi. Berdasarkan pengalaman di lapangan, di sini coba diidentifikasi permasalahan yang pernah dihadapi, yang menyebabkan pembelajaran PKn cenderung kurang menarik, dianggap sepele, membosankan, dan kesan negatif lainnya.

Begitu juga KD menentukan sikap terhadap pengaruh globalisasi yang terjadi di lingkungannya. Dengan mendiskusikan masalah ini siswa akan terlatih berpikir kritis 
terhadap fenomena di lingkungannya. Dengan kemampuan berpikirnya itulah diharapkan siswa akan mampu menghadapi semua persoalan, baik kini maupun bagi kehidupannya di masa mendatang. Semua bermula dari realita.

Dalam mata pelajaran PKn, pengembangan nilai-nilai afeksi dan karakter harus menjadi prioritas. Apalah artinya pandai secara akademik tanpa diimbangi karakter dan akhlak mulia. Dalam rangka pengembangan nilai-nilai afeksi dan karakter ini, peran guru amat penting. Sebab, guru adalah figur yang banyak dicontoh muridnya, terutama untuk tingkat SD. Guru tidak cukup memberi contoh, namun harus dapat menjadi contoh.

Akhirnya,penulis menegaskan, pendidik perlu menerapkan metode dan model pembelajaran yang bervariasi serta media pembelajaran yang inovatif. Dengan begitu, peserta didik tidak akan merasa bosan dalam mengikuti proses pembelajaran PKn.

Pembelajaran PKn haruslah lebih berkembang, tidak hanya terfokus pada kebiasaan dengan strategi atau urutan penyajian sebagai berikut: diajarkan definisi, diberikan contoh-contoh dan diberikan latihan soal. Hal ini sangat memungkinkan peserta didik mengalami kesulitan dalam menerima konsep yang tidak berasosiasi dengan pengalaman sebelumnya. Dalam latihan soal sebaiknya dihadapi bentuk soal cerita yang mungkin terkait dengan terapkan PKn atau kehidupan sehari-hari.

Memperhatikan uraian di atas keadaan yang sama dialami juga oleh peserta didik kelas VI.B SD Negeri 26 Lubuklinggau, peserta didik masih merasa kesulitan, takut dan kurang berani bertanya terhadap hal-hal yang belum dipahami, sementara itu peneliti kurang melibatkan peserta didik dalam pembelajaran. Keadaan ini jika dibiarkan maka nilai pelajaran PKn akan semakin menurun dan gagal dalam memperoleh nilai ketuntasan minimal yang telah ditentukan. Untuk mengatasi masalah tersebut seorang guru harus mampu memberikan motivasi terhadap peserta didik melalui pengelolaan kelas yang menarik dan melibatkan peserta didik dalam menemukan konsep.

Dalam pembelajaran guru tidak menggunakan alat bantu pembelajaran. Hal inilah yang diduga menyebabkan lemahnya peserta didik 
dalam memahami konsep-konsep dasar PKn, hal ini bisa dilihat dari hasil belajar yang rendah. Pengalaman peneliti sebagai guru PKn di kelas VI.B SD Negeri 26 Lubuklinggau sebelum melaksanakan pembelajaran sudah berusaha maksimal, mulai dari persiapan RPP, media hingga strategi pembelajaran dan pengelolaan kelas. Namun disisi lain peneliti sebagai guru memang masih cenderung menggunakan metode mengajar yang monoton yaitu metode ceramah, kondisi ini ternyata membuat peserta didik menjadi bosan, jemu dan tidak tertarik untuk belajar. Guru kurang mampu mengelola kelas dengan baik, sehingga banyak diantara peserta didik yang acuh tak acuh terhadap pembelajaran yang sedang dilakukan oleh guru bahkan sebagian diantaranya lebih sering mengerjakan tugas lain.

Untuk mengatasi hal tersebut perlu diupayakan langkah-langkah yang dapat dilaksanakan baik oleh peserta didik maupun guru. Guru hendaknya mengemas proses belajar mengajar dengan metode yang tepat dan menarik dalam penyajiannya. Salah satu langkahnya adalah menggunakan metode pembelajaran yang mampu meningkatkan pola interaksi guru dan peserta didik yaitu dengan metode kooperatif tipe (TPS) Think Pair Share. Think-pair-share pertama kali dikembangkan oleh Frang Lyman dan koleganya di Universitas Maryland sesuai yang dikutip Arends (1997), menyatakan bahwa think-pair-share merupakan suatu cara yang efektif untuk membuat variasi suasana Think Pair Share kelas. Sebab dalam TPS interaksi antara guru dan peserta didik, antar peserta didik dengan peserta didik, dan suasana yang baru dan menggairahkan, muncul melalui Think Pair Share kelompok, bertanya jawab maupun menyampaikan informasi kepada sesama teman dapat berjalan secara efektif dan efisien, sehingga pada akhirnya dapat meningkatkan hasil belajar peserta didik itu sendiri, baik aspek kognitif, afektif maupun psikomotorik.

Berdasarkan latar belakang yang dikemukakan di atas, maka yang menjadi permasalahan dalam penelitian ini adalah bagaimanakah upaya meningkatkan pemahaman peranan politik luar negeri Indonesia di kelas VI.B SD Negeri 26 Lubuklinggau melalui model 
pembelajaran Think Pair Share?

Tujuan yang akan dicapai dalam penelitian ini adalah untuk meningkatkan pemahaman peranan politik luar negeri indonesia pembelajaran PKn di kelas VI.B SD Negeri 26 Lubuklinggau dengan menggunakan model kooperatif tipe Think Pair Share (TPS).

Think-pair-share pertama kali dikembangkan oleh Frang Lyman dan koleganya di Universitas Maryland sesuai yang dikutip Arends (1997), menyatakan bahwa think-pair-share merupakan suatu cara yang efektif untuk membuat variasi suasana Think Pair Share kelas. Dengan asumsi bahwa semua resitasi atau Think Pair Share membutuhkan pengaturan untuk mengendalikan kelas secara keseluruhan, dan prosedur yang digunakan dalam think-pair-share dapat memberi peserta didik lebih banyak waktu berpikir, untuk merespons dan saling membantu. Guru memperkirakan hanya melengkapi penyajian singkat atau peserta didik membaca tugas, atau situasi yang menjadi tanda tanya. Sekarang guru menginginkan peserta didik mempertimbangkan lebih banyak apa yang telah dijelaskan dan dialami. Guru memilih menggunakan think-pair-share untuk membandingkan tanya jawab kelompok keseluruhan. (Trianto, 2007:132-133).

Belajar merupakan suatu hal yang sangat penting bagi seseorang, karena belajar merupakan usaha sadar dalam proses belajar mengajar yang terjadi di dalam diri seseorang, menurut Oemar Hamalik (2003 : 40) mengatakan bahwa "Belajar adalah suatu proses perubahan pada tingkah laku manusia dengan adanya interaksi maupun lingkungan alam sekitar".

Menurut Slameto menyatakan bahwa belajar adalah suatu proses usaha yang dilakukan seseorang untuk memperoleh suatu perubahan tingkah laku yang baru secara keseluruhan, sebagai hasil pengalamannya sendiri dalam interaksi dengan lingkungannya (Slameto, 2010:2).

Belajar merupakan sebuah proses yang kompleks yang terjadi pada semua orang dan berlangsung seumur hidup. Salah satu pertanda bahwa seseorang telah belajar sesuatu adalah adanya perubahan tingkah laku dalam dirinya.Perubahan tingkah laku tersebut menyangkut perubahan yang bersifat pengetahuan (kognitif), dan 
keterampilan (psikomotor) maupun yang menyangkut nilai dan sikap (afektif). (Siregar dan Hartini Nara, 2010:3)

Burton mengemukakan bahwa belajar adalah proses perubahan tingkah laku pada diri individu karena adanya interaksi antara individu dengan individu dan individu dengan lingkungannya.Sementara Ernest R.Hilgard dalam Introduction to psychology mendefinisikan belajar sebagai suatu proses perubahan kegiatan, reaksi terhadap lingkungan. (Siregar dan Hartini, 2010:4)

Belajar adalah suatu proses, suatu kegiatan dan bukan suatu hasil atau tujuan. Belajar bukan hanya mengingat, akan tetapi lebih luas daripada itu, yakni ,mengalami. (Hamalik, 2010:36).

Hasil belajar peserta didik pada hakekatnya adalah perubahan tingkah laku. Tingkah laku sebagai hasil belajar dalam pengertian yang luas mencakup bidang kognitif, afektif dan psikomotorik.(Sudjana, 2010:3)

Hasil belajar merupakan proses untuk menentukan nilai belajar peserta didik melalui kegiatan penilaian dan/atau pengukuran hasil belajar. Berdasarkan pengertian evaluasi hasil belajar kita dapat menengarai tujuan utamanya adalah untuk mengetahui tingkat keberhasilan yang dicapai oleh peserta didik setelah mengikuti suatu kegiatan pembelajaran, dimana tingkat keberhasilan tersebut kemudian ditandai dengan skala nilai berupa huruf atau angka atau simbol.(Dimyati dan Mudjiono, 2009:200)

Hasil belajar mempunyai hubungan yang erat dengan belajar itu sendiri. Untuk mengetahui sampai mana perubahan yang terjadi pada diri sendiri baik itu perubahan tingkah laku dan kecakapan dapat dilihat dari hasil belajarnya. Secara umum untuk mengetahui hasil belajar peserta didik dapat diklasifikasikan kedalam tiga ranah hasil belajar, ranah kognitif, ranah afektif, dan ranah psikomotorik. Jadi hasil belajar dapat dikatakan sebagai pengetahuan yang dikuasai oleh peserta didik sebagai hasil dari kemampuan penyerapan pengetahuan dalam proses belajar mengajar baik secara perorangan maupun secara kelompok yang diintegrasikan kedalam pelajaran.

\section{METODE}

Sesuai dengan permasalahan dan tujuan penelitian, maka jenis 
penelitian ini adalah penelitian tindakan (action), pengamatan tindakan kelas (PTK). Penelitian (observation) dan perenungan tindakan kelas merupakan bentuk (reflection). Selanjutnya diuraikan penelitian yang dilaksanakan secara langkah - langkah kegiatan yang lansung oleh guru dalam praktek dilaksanakan dari dua kali pertemuan pembelajaran, dimana guru (peneliti) disetiap siklus yang meliputi: mengadakan tindakan tertentu berdasarkan masalah-masalah penting dilapangan yang harus segera diatasi.

Penelitian ini dilaksanakan di Jalan Kenanga II Kel. Kenanga Kec. Lubuklinggau Utara II kota Lubuklinggau SD Negeri 26 Lubuklinggau. Waktu penelitan pada semester genap bulan Januari-Maret tahun pelajaran 2016/2017.

Kelas yang menjadi subjek penelitian adalah kelas VI.B SD Negeri 26 Lubuklinggau yang peserta didiknya berjumlah 25 orang siswa pada pokok bahasan memahami peranan politik luar negeri Indonesia dalam era globalisasi. Indikator inerja dalam penelitian ini yaitu apabila siswa telah tuntas belajar dengan KKM 70 atau sebanyak $85 \%$ siswa tuntas belajar secara klasikal.

Penelitian tindakan kelas ini menggunakan model yang dikembangkan oleh Kemmis dan Mc. Teggart, terdiri dari dua siklus, tiap siklus terdiri atas perencanaan (plan), perencanaan, pelaksanaan, obsevasi, dan refleksi.

\section{PEMBAHASAN}

\section{Pra Siklus}

Sebelum mengadakan penelitian dengan menerapkan metode Think Pair Share, terlebih dahulu peneliti mengumpulkan data hasil belajar siswa berdasarkan nilai ulangan harian mereka dan menganalisa hasil ulangan harian peserta didik kelas VI.B SD Negeri 26 Lubuklinggau. Nilai ulangan harian ini didapat dari pembelajaran sebelum menerapkan metode Think Pair Share. Hasil dari nilai ulangan harian tersebut dapat dilihat pada tabel berikut ini:

Tabel 1 Hasil Tes Formatif Pra Siklus

\begin{tabular}{|c|l|c|}
\hline No. & \multicolumn{1}{|c|}{ Uraian } & $\begin{array}{c}\text { Hasil } \\
\text { pra } \\
\text { Siklus }\end{array}$ \\
\hline \hline 1. & $\begin{array}{l}\text { Nilai rata-rata tes } \\
\text { formatif }\end{array}$ & 69,20 \\
\hline 2. & $\begin{array}{l}\text { Jumlah siswa yang } \\
\text { tuntas belajar }\end{array}$ & 15 \\
\hline 3. & $\begin{array}{l}\text { Persentase ketuntasan } \\
\text { belajar }\end{array}$ & 60,00 \\
\hline
\end{tabular}


Berdasarkan data di atas dapat diketahui bahwa siswa yang nilainya mencapai kriteria ketuntasan minimal yang sudah ditetapkan yaitu, siswa yang mendapatkan nilai di atas/sama dengan 70 hanya berjumlah 15 orang dengan persentase $60,00 \%$. Dan siswa yang mendapatkan nilai kurang dari 70 berjumlah 10 orang. Angka ini masih jauh dari indikator keberhasilan yang diharapkan yaitu $85 \%$ siswa yang memperoleh nilai diatas 70 .

Berdasarkan hasil Think Pair Share kecil dengan teman sejawat maka ditentukanlah model pembelajaran kooperatif tipe Think Pair Share yang akan digunakan dalam proses tindakan perbaikan PKn yang diharapkan dapat meningkatkan hasil belajar PKn yang pelaksanaannya akan dilaksanakan dalam 2 siklus.

\section{Siklus I}

Pelaksanaan kegiatan belajar mengajar untuk siklus I dilaksanakan pada hari Selasa jam ke 5 dan ke 6 tanggal 13 Februari 2017 di kelas VI.B SD Negeri 26 Lubuklinggau dengan jumlah peserta didik 25 peserta didik. Dalam hal ini peneliti bertindak sebagai guru. Adapun proses belajar mengajar mengacu pada rencana pelaksanaan pembelajaran yang telah dipersiapkan. Langkahlangkah kegiatan adalah sebagai berikut: Guru menjelaskan materi mengenai politik luar negeri bebas aktif, menjelaskan alasan mengapa Indonesia mengambil sikap netral, Guru melanjutkan dengan menjelaskan tujuan politik luar negeri. Setelah itu guru mmengajukan suatu pertanyaan atau masalah yang dikaitkan dengan pelajaran yang telah dijelaskan, dan meminta peserta didik menggunakan waktu beberapa menit untuk berpikir sendiri jawaban atau masalah. Peserta didik membutuhkan penjelasan bahwa bebicara atau mengerjakan bukan bagian berpikir.

Selajutnya guru meminta peserta didik untuk bepasangan dan menThink Pair Sharekan apa yang telah mereka peroleh. Interaksi selama waktu yang disediakan dapat menyatukan jawaban jika suatu pertanyaan yang diajukan atau menyatukan gagasan apabila suatu masalah khusus yang diidentifikasi. Secara normal guru memberikan waktu tidak lebih dari 4 atau 5 menit untuk berpasangan.

Berdiskusi secara berpasangan mengenai apa yang dimaksud dengan perang dingin. Guru bertanya 
mengenai defenisi netral. Berdiskusi mengenai definisi politik. Guru meminta semua siswa untuk mengamati posisi geografis Indonesia yang strategis dalam percaturan politik dunia.

Guru bertanya jawab tentang hal-hal yang belum diketahui siswa. Guru bersama siswa bertanya jawab meluruskan kesalahan pemahaman, memberikan penguatan dan penyimpulan.

$$
\text { Pengamatan dilaksanakan }
$$

bersamaan dengan pelaksaaan belajar mengajar. Pada akhir proses belajar mengajar peserta didik diberi tes formatif I dengan tujuan untuk mengetahui tingkat keberhasilan peserta didik dalam proses belajar mengajar yang telah dilakukan.

Aspek-aspek yang mendapatkan kriteria kurang baik adalah memotivasi siswa, melatih keterampilan kooperatif, mengawasi setiap kelompok secara bergiliran, mengatur siswa dalam kelompokkelompok belajar. Sedangkan untuk antusias guru dan antusias siswa dalam kegiatan sudah mendapat respon cukup baik dari penilaian. Aspek -aspek yang mendapat penilaian kurang baik di atas, merupakan suatu kelemahan yang terjadi pada siklus I. Dan akan dijadikan bahan kajian untuk refleksi dan revisi yang akan dilakukan pada siklus II.

Hasil berikutnya adalah tes formatif peserta didik seperti terlihat pada tabel berikut.

Tabel 2 Hasil Tes Formatif Siklus I

\begin{tabular}{|l|l|l|}
\hline No. & \multicolumn{1}{|c|}{ Uraian } & \multicolumn{1}{|c|}{$\begin{array}{c}\text { Hasil } \\
\text { Siklus I }\end{array}$} \\
\hline \hline 1. & Nilai rata-rata tes formatif & 72,40 \\
\hline 2. & $\begin{array}{l}\text { Jumlah siswa yang tuntas } \\
\text { belajar }\end{array}$ & 18 \\
\hline 3. & $\begin{array}{l}\text { Persentase ketuntasan } \\
\text { belajar }\end{array}$ & 72,00 \\
\hline
\end{tabular}

Dari tabel di atas dapat dijelaskan bahwa dengan menerapkan pembelajaran dengan Model kooperatif tipe Think Pair Share (TPS) diperoleh nilai rata-rata hasil belajar peserta didik adalah 72,40 dan ketuntasan belajar mencapai $72,00 \%$ atau ada 18 peserta didik dari 25 peserta didik sudah tuntas belajar. Hasil tersebut menunjukkan bahwa pada siklus pertama secara klasikal peserta didik belum tuntas belajar, karena peserta didik yang memperoleh nilai $\geq 70$ hanya sebesar $72,00 \%$ lebih kecil dari persentase ketuntasan yang 
dikehendaki yaitu sebesar $85 \%$. Hal ini disebabkan karena peserta didik masih belum bisa menyesuaian diri dengan metode pembelajaran yang baru tersebut.

Dalam pelaksanaan kegiatan belajar mengajar diperoleh informasi dari hasil pengamatan sebagai berikut: Setiap peserta didik membutuhkan koordinasi secara bersamaan dari berbagai aktivitas.Tiap kelompok kurang perhatian khusus dalam kegiatan. Peralihan dari seluruh kelas ke kelompok kecil dapat menyita waktu pengajaran yang berharga. Untuk itu guru harus dapat membuat perencanaan yang seksama sehingga dapat meminimalkan jumlah waktu yang terbuang.

Pelaksanaan kegiatan belajar mengajar pada siklus I ini masih terdapat kekurangan, sehingga perlu adanya refisi untuk dilakukan pada siklus berikutnya. Sangat memerlukan kemampuan dan ketrampilan guru, waktu pembelajaran berlangsung guru melakukan intervensi secara maksimal. Mengubah kebiasaan peserta didik belajar dari yang dengan cara mendengarkan ceramah diganti dengan belajar berfikir memecahkan masalah secara kelompok, hal ini merupakan kesulitan sendiri bagi peserta didik. Guru perlu lebih terampil dalam memotivasi peserta didik dan lebih jelas dalam menyampaikan tujuan pembelajaran. Dimana peserta didik diajak untuk terlibat langsung dalam setiap kegiatan yang akan dilakukan.

\section{Siklus II}

Pelaksanaan kegiatan belajar mengajar untuk siklus II dilaksanakan pada tanggal 27 Februari 2017 di kelas VI.B SD Negeri 26 Lubuklinggau dengan jumlah peserta didik 25 peserta didik. Dalam hal ini peneliti bertindak sebagai guru. Adapun proses belajar mengajar mengacu pada rencanapelaksanaan pembelajaran dengan memperhatikan revisi pada siklus I, sehingga kesalahan atau kekurangan pada siklus I tidak terulang lagi pada siklus II. Langkah kegiatan siklus II sesuai model Think Pair Share adalah sebagai berikut: Guru mengajukan suatu pertanyaan atau masalah yang dikaitkan dengan pelajaran yaitu contoh peranan politik luar negeri Indonesia dalam percaturan internasional. Peserta didik membutuhkan penjelasan bahwa bebicara atau mengerjakan bukan 
bagian berpikir. Selajutnya guru meminta peserta didik untuk bepasangan dan Think Pair Sharekan apa yang telah mereka peroleh mengenai politik luar negeri bebas aktif. Interaksi selama waktu yang disediakan dapat menyatukan jawaban jika suatu pertanyaan yang diajukan atau menyatukan gagasan apabila suatu masalah khusus yang diidentifikasi. Secara normal guru memberikan waktu tidak lebih dari 4 atau 5 menit untuk berpasangan dan bersama-sama menyebutkan negaranegara anggota Konferensi Asia Afrika. Pada langakah akhir, guru meminta pada pasangan-pasangan untuk berbagi dengan keseluruhan kelas yang telah mereka bicarakan dan membahas penyelenggaraan KTT Gerakan Non Blok. Guru menerangkan Konferensi Asia Afrika. Guru bertanya mengenai defenisi Non Blok. Bertanya jawab mengenai tujuan Indonesia bergabung dengan Gerakan Non Blok. Guru menerangkan Perserikatan BangsaBangsa (PBB). Siswa diingatkan untuk mempelajari kembali materi mengenai politik luar negeri bebas aktif dan peranan politik luar negeri RI dalam percaturan internasional.
Guru bertanya jawab tentang hal-hal yang belum diketahui siswa. Guru bersama siswa bertanya jawab meluruskan kesalahan pemahaman, memberikan penguatan dan penyimpulan

Pada akhir proses belajar mengajar peserta didik diberi tes formatif II dengan tujuan untuk mengetahui tingkat keberhasilan peserta didik dalam proses belajar mengajar yang telah dilakukan. Instrumen yang digunakan adalah tes formatif II.

Aspek-aspek yang diamati pada kegiatan belajar mengajar (siklus II) yang dilaksanakan oleh guru dengan menggunakan model pembelajaran kooperatif tipe Think Pair Share (TPS) mendapatkan penilaian cukup baik dari pengamat adalah memotivasi peserta didik, menghubungkan dengan pelajaran sebelumnya, membimbing peserta didik membuat rangkuman, serta pada antusiasme guru dan peserta didik. Penyempurnaan aspek-aspek diatas dalam menerapkan metode pembelajaran TPS dengan pemberian tugas diharapkan dapat berhasil semaksimal mungkin. 
Hasil berikutnya adalah tes formatif peserta didik seperti terlihat pada tabel berikut.

Tabel 3 Hasil Tes Formatif Siklus II

\begin{tabular}{|c|l|c|}
\hline No. & \multicolumn{1}{|c|}{ Uraian } & $\begin{array}{c}\text { Hasil } \\
\text { Siklus } \\
\text { II }\end{array}$ \\
\hline \hline 1. & Nilai rata-rata tes formatif & 76,80 \\
\hline 2. & $\begin{array}{l}\text { Jumlah siswa yang tuntas } \\
\text { belajar }\end{array}$ & 22 \\
\hline 3. & $\begin{array}{l}\text { Persentase ketuntasan } \\
\text { belajar }\end{array}$ & 88,00 \\
\hline
\end{tabular}

Berdasarkan tabel diatas diperoleh nilai rata-rata tes formatif sebesar 76,80 dan dari 25 peserta didik, yang telah tuntas ialah semua siswa tuntas dan tidak ada peserta yang tidak tuntas. Maka secara klasikal ketuntasan belajar yang telah tercapai sebesar 88,00\% (kategori tuntas). Hasil pada siklus II ini mengalami peningkatan lebih baik dari siklus I. Adanya peningkatan hasil belajar pada siklus II ini dipengaruhi oleh adanya peningkatan kemampuan peserta didik dalam mempelajari materi pelajaran yang telah diterapkan selama ini. Hal ini dipengaruhi oleh kemampuan guru dalam mengelola proses belajar mengajar selama kegiatan pembelajaran yang berlangsung.

Pada tahap ini akah dikaji apa yang telah terlaksana dengan baik maupun yang masih kurang baik dalam proses belajar mengajar dengan penerapan belajar aktif. Dari data-data yang telah diperoleh dapat duraikan sebagai berikut: Setiap peserta didik telah mendapatkan koordinasi yang baik secara bersamaan dari berbagai aktivitas. Tiap kelompok telah mendapat perhatian khusus dalam kegiatan. Waktu yang digunakan untuk menjadikan sebuah kelompok tidak banyak terbuang. Banyak kelompok yang sudah mandiri dan tidak banyak lapor. Hasil belajar siswsa pada siklus II mencapai ketuntasan.

Pada siklus II guru telah menerapkan belajar aktif dengan baik dan dilihat dari aktivitas peserta didik serta hasil belajar peserta didik pelaksanaan proses belajar mengajar sudah berjalan dengan baik. Maka tidak diperlukan revisi terlalu banyak, tetapi yang perlu diperhatikan untuk tindakan selanjutnya adalah memaksimalkan dan mempertahankan apa yang telah ada dengan tujuan agar pada pelaksanaan proses belajar mengajar selanjutnya penerapan belajar aktif dapat meningkatkan proses belajar mengajar sehingga tujuan pembelajaran dapat tercapai. 


\section{Pembahasan}

Melalui hasil peneilitian ini menunjukkan bahwa pembelajaran terstrutur dengan memiliki dampak positif dalam meningkatkan hasil belajar peserta didik. Hal ini dapat dilihat dari semakin mantapnya pemahaman dan penguasaan peserta didik terhadap materi yang telah disampaikan guru selama ini (ketuntasan belajar meningkat dari pra siklus, siklus I dan II yaitu masingmasing $60,00 \%, 72,00 \%$ dan $88,00 \%$. Pada siklus II ketuntasan belajar peserta didik secara klasikal telah tercapai dan mengalami peningkatan yang sangat baik.

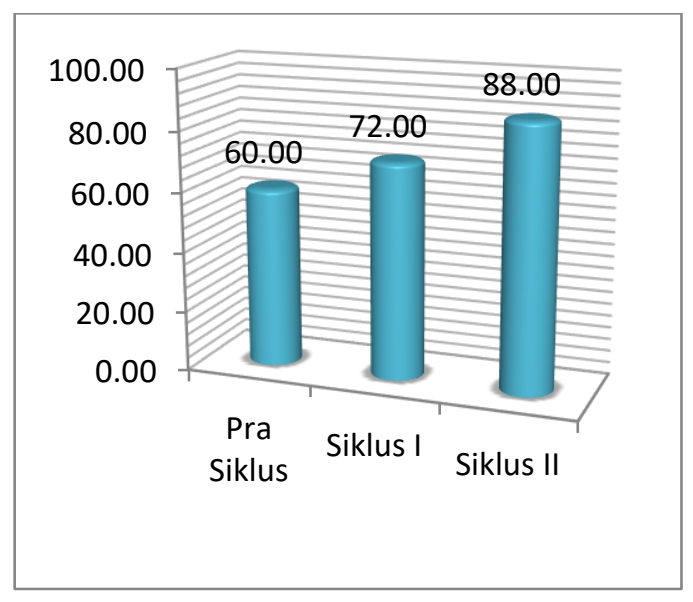

Grafik 1 Pencapaian KKM Klasikal

\section{KESIMPULAN}

Berdasarkan hasil penelitian yang telah dikemukakan pada bab sebelumnya, maka kesimpulan yang dapat diambil dalam penelitian ini adalah Model pembelajaran kooperatif tipe Think Pair Share (TPS)) memiliki dampak positif dalam meningkatkan hasil belajar PKn peserta didik kelas VI.B SD Negeri 26 Lubuklinggau yang ditandai dengan peningkatan ketuntasan belajar peserta didik dalam setiap siklus, yaitu pra siklus, siklus I dan siklus II masing-masing $60,00 \%$, $72,00 \%$ dan $88,00 \%$. Penerapan model pembelajaran kooperatif tipe Think Pair Share (TPS)) mempunyai pengaruh positif, yaitu dapat meningkatkan hasil belajar peserta didik yang ditunjukan dengan rata-rata jawaban peserta didik yang menyatakan bahwa peserta didik tertarik dan berminat terhadap model pembelajaran kooperatif tipe Think Pair Share (TPS)) sehingga mereka menjadi termotivasi untuk belajar.

Dari hasil penelitian yang diperoleh dari uraian sebelumnya agar proses belajar mengajar Pendidikan Kewarganegaraan lebih efektif dan lebih memberikan hasil yang optimal bagi peserta didik, maka disampaikan saran sebagai berikut:

Diharapkan bagi peserta didik untuk selalu berpartisipasi secara aktif dan bertanggung jawab, dan bertindak secara cerdas dalam kegiatan bermasyarakat, berbangsa, dan 
bernegara, serta anti-korupsi sesuai pembelajaran PKn. Untuk melaksanakan pembelajaran memerlukan persiapan yang cukup baik, sehingga guru harus mampu menentukan atau memilih topik yang benar-benar bisa diterapkan dengan pembelajaran terstruktur dengan pemberian balikan dalam proses belajar mengajar sehingga diperoleh hasil yang optimal.

\section{DAFTAR PUSTAKA}

Arends, Richard I. 1997. Cooperative

Learning: Mempraktikkan

Cooperative Learning di

Ruang-Ruang Kelas. Jakarta:

Grasindo.

Dimyati dan Mudjiono. (2009).

Belajar dan Pembelajaran.

Jakarta: Rineka Cipta

Hamalik, Oemar. 2003. Kurikulum dan Pembelajaran. Jakarta: PT. Bumi Aksara. 2010. Proses

Belajar Mengajar. Bumi

Aksara: Bandung.

Nara, Hartini. 2010. Keterampilan Psikomotorik. Jakarta:

Rineka Cipta
Slameto, 2010. Belajar dan Faktor yang Mempengaruhinya. Jakarta: Rineka Cipta.

Trianto. 2007. Model-model Pembelajaran Inovatif Berorientasi Konstruktivistik. Jakarta : Prestasi Pustaka 